\title{
BAGAIMANA BELAJAR BAHASA ASING
}

\author{
Oleh: Lia Malia
}

\begin{abstract}
Abstrak
Dewasa ini kebutuhan masyarakat Indonesia akan bahasa asing semakin meningkat. Seiring dengan semakin meningkatnya kebutuhan tersebut, semakin banyak pula tempat-tempat kursus bahasa asing yang menawarkan berbagai kemudahan

Dalam pengajaran bahasa asing dikenal beberapa metode pengajaran, metode gramatik, metode audio lingual, metodemetode langsung, metode langsung, metode bermain, dan pendekatan komunikatif. Dari sejumlah metode yang dibicarakan, metode yang paling disarankan dalam tulisan ini untuk mencapai optimalisasi pembelajaran bahasa asing yang berwujud communicative competence, adalah pendekatan komunikatif yang diperkuat dengan metode bermain.
\end{abstract}

\section{Pendahuluan}

Bila kita membicarakan masalah pengajaran bahasa, sering muncul istilah bahasa ibu (Muttersprache) dan bahasa asing (Fremdsprache). Bagi sebagian besar orang Indonesia, terutama yang tinggal di kota-kota besar, yang mempelajari bahasa asing, yang dimaksud dengan bahasa ibu adalah bahasa Indonesia. Sebaliknya, pengertian bahasa asing dalam tulisan ini adalah bahasa yang bukan bahasa ibu. Menurut Wahrig (1980: 1374) Fremdsprache ist Sprache, die nicht Muttersprache ist (bahasa asing ialah bahasa yang bukan bahasa ibu).

Jika kita mempelajari bahasa asing, sebenamya bahasa asing itu belum tentu asing sama sekali. Sebagai contoh, kita dapat mengenal kata-kata berikut ini, walaupun kita tidak mengenal bahasanya. Itu disebabkan kata-kata tersebut bersifat universal.

\begin{tabular}{|c|c|c|c|}
\hline $\begin{array}{l}\text { Itali } \\
\text { cultura } \\
\text { cinematografi } \\
\text { gallerie-musei }\end{array}$ & $\begin{array}{l}\text { Spanyol } \\
\text { salon } \\
\text { nacional } \\
\text { programas }\end{array}$ & $\begin{array}{l}\text { Norwegia } \\
\text { stereo } \\
\text { musikk } \\
\text { sport }\end{array}$ & $\begin{array}{l}\text { Turki } \\
\text { radyo } \\
\text { otomobil } \\
\text { otobus }\end{array}$ \\
\hline $\begin{array}{l}\text { teatri-concerti } \\
\text { alla radio }\end{array}$ & $\begin{array}{l}\text { teatros } \\
\text { importa- } \\
\text { ciom }\end{array}$ & $\begin{array}{l}\text { radio } \\
\text { optikk }\end{array}$ & televizyon \\
\hline
\end{tabular}




$\begin{array}{lll}\text { alla televisi- } & \text { ekporta- } & \text { foto } \\ \text { one } & \text { cion } & \text { film }\end{array}$

Di bandara-bandara internasional kita dapat menemukan simbol- simbol internasional. Contoh yang lain lagi adalah nama-nama bulan dalam beberapa bahasa:

$\begin{array}{llllll}\text { Perancis } & \text { Jerman } & \text { Swedia } & \text { Denmark } & \text { Malasia } & \text { Indonesia } \\ \text { janvier } & \text { Januar } & \text { januari } & \text { januar } & \text { yanuari } & \text { Januari } \\ \text { fevrier } & \text { Februar } & \text { februari } & \text { februar } & \text { februari } & \text { Pebruari } \\ \text { mars } & \text { Marz } & \text { mars } & \text { marts } & \text { mart } & \text { Maret } \\ \text { avril } & \text { April } & \text { april } & \text { april } & \text { april } & \text { April }\end{array}$

Dari contoh-contoh tersebut dapat dilihat, bahwa bahasa asing belum tentu asing sama sekali. Walaupun tidak mengerti bahasa asing yang dipakai, kita dapat menangkap informasi yang ingin disampaikan.

\section{Tempat-tempat Belajar Bahasa Asing}

Belajar bahasa asing tidak hanya mempelajari bahasanya saja, melainkan juga belajar memahami apa yang ada di balik suatu ungkapan dan juga belajar menjelaskan dan mengungkapkan sesuatu kepada orang lain secara lisan maupun tertulis dengan menggunakan bahasa asing tersebut termasuk kebudayaannya. Untuk itu, kita haruslah pandai-pandai mencari tempat yang tepat untuk mempelajarinya. Ada beberapa pilihan untuk dijadikan tempat belajar bahasa asing, di antaranya adalah sebagai berikut:

(1) Sekolah

(2) Tempat kursus dasar

(3) Lembaga kebudayaan luar negeri, seperti misalnya

Goethe-Institut untuk bahasa Jerman, LIP (Lembaga Indonesia Perancis) untuk bahasa Perancis. Khususnya untuk belajar bahasa Jerman di Yogyakarta di IGBJI (lkatan Guru Bahasa Jerman Indonesia) karena di Indonesia hanya ada tiga Goethe-Institut yaitu di Jakarta, Bandung, dan Surabaya (tidak aktif lagi). Dalam penyelenggaraan ujiannya, khusus $\mathrm{ZDaF}$ (Zertifikat Deutsch als Fremdsprache) setingkat TOEFL dalam bahasa Inggris, bahan-bahan ujiannya didatangkan langsung dari kota Munchen (Goethe-Institut pusat), dengan demikian ijasah atau sertifikat ujian $\mathrm{ZDaF}$ tersebut berlaku secara internasional.

(4) Kursus bahasa di dalam dan di luar negeri.

Kursus bahasa di luar negeri untuk bahasa Jerman menerima peserta kursus sebagai persiapan untuk masuk perguruan tinggi di Jerman. Tetapi, apabila peserta kursus mengikuti kursus persiapan tersebut di tempat-tempat kursus yang diselenggarakan oleh pergururan tinggi, tidak periu membayar uang 
kursus. Seandainya harus membayar pun biayanya lebih murah bila aibandingkan dengan biaya kursus di tempat kursus swasta.

(5) Kursus bahasa di lingkungan perusahaan yang diselenggarakan oleh perusahaan-perusahaan besar.

Bagi pembelajar bahasa asing, selain faktor tempat belajar yang harus diperhatikan juga faktor pengajar. Dalam proses belajar mengajar baik di sekolah maupun di tempat-tempat kursus pengajar memegang peranan penting, karena itu, menurut Maharlin Sihombing, seorang pengajar harus memiliki kualifikasi dasar sebagai berikut.

(1) Menguasai bahan bidang studi dalam kurikulum sekolah.

(2) Dapat mengelola program belajar mengajar, yang meliputi:

(a) Merumuskan tujuan instruksional khusus.

(b) Mengenal dan dapat menggunakan metode mengajar.

(c) Memilih dan menyusun prosedur instruksional yang tepat.

(d) Melaksanakan program belajar mengajar.

(e) Mengenal kemampuan anak didik.

(f) Merencanakan dan Melaksanakan pengajaran renedial.

(3) Mengelola kelas.

(4) Menggunakan media/sumber.

(5) Menguasai landasan-landasan pendidikan.

(6) Mengelola interaksi belajar mengajar.

(7) Menilai siswa untuk kepentingan pengajaran.

(8) Mengenal fungsi dan program pelayanan bimbingan dan penyuluhan sekolah.

(9) Mengenal dan menyelenggarakan administrasi sekolah.

(10)Memahami prinsip-prinsip dan menafsirkan hasil-hasil penelitian.

Seandainya faktor tempat belajar dan pengajar telah memenuhi syarat, faktor lain yang tak kalah pentingnya adalah metode. Dalam uraian di atas telah disinggung tentang kemampuan dasar guru, salah satu di antaranya adalah mengenal dan dapat menggunakan metode mengajar. Dengan demikian, aktivitas guru dalam kegiatan belajar mengajar tidak dapat dipisahkan dengan metode men gajar dengan baik, sedang metode yang dipilih dan dipakai kurang tepat, hasil yang diperoleh pun belum tentu memuaskan. Begitu pula sebaliknya, sean dainya metode yang dipilih sudah tepat, tetapi guru tidak mengenal dan menggunakan, hasil belajar mengajarnya pun tidak akan baik. Dengan kata lain, guru dan metode merupakan satu kesatuan, di samping ada faktor lain yang mempengaruhi keberhasilan proses belajar mengajar, yaitu situasi pada saat berlangsungnya proses belajar mengajar dan sarana yang dipakai dalam proses belajar mengajar. 
Berbicara mengenai pengajaran bahasa, sarana merupakan faktor yang tidak kalah pentingnya di samping faktor-faktor lainnya yang telah disebutkan di atas. Dari sekian sarana penting yang dipergunakan dalam pengajaran bahasa, laboratorium bahasa merupakan sarana yang terpenting. Dengan bantuan laboratorium bahasa memungkinkan pembelajar bahasa asing mendengar ragam percakapan autentik, sehingga pembelajar dapat meniru dan memanfaatkannya. Dengan cara ini pula guru dapat membetulkan kesalahan pengucapan yang salah. Pendidikan di laboratorium bahasa merupakan metode aktif karena setiap pembelajar berkesempatan memperbaiki pengetahuan bahasanya. Manfaat yang lain adalah pembelajar dapat memperbaiki pengucapan, mendengar ungkapan, melatih ungkapan ataupun kalimat secara berulang-ulang. Di samping itu, pemúelajar juga dapat mendengarkan kembali kalimat-kalimatnya atau membandingkan susunan kaiimat, mengulang atau menjawab sesuai dengan pembicaraan tanpa mengganggu teman-teman dan gurunya. Berdasarkan manfaat yang diberikan laboratorium bahasa, keberadaannya dalam pengajaran bahasa ada alat bantu lainnya yang diperlukan dalam pengajaran bahasa di antaranya dias dan diaproyektornya, film strip, OHP, dan televisi.

Secara garis besar uraian di atas dapat diringkas sebagai berikut.

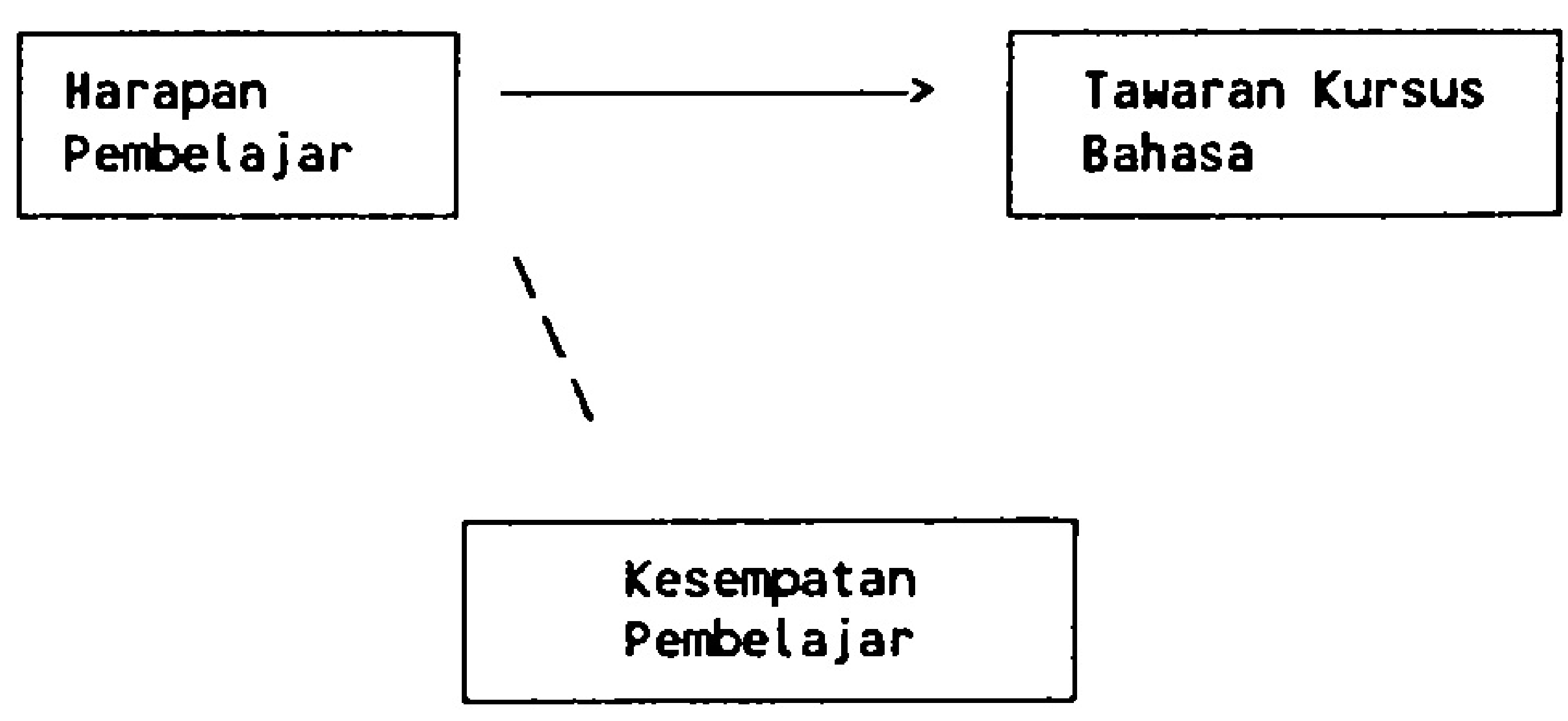

Jika pembelajar sudah mengetahui secara pasti apa yang dibutuhkan, di mana dia akan mempelajari bahasa asing, dia haruslah menanyakan di tempat kursus tersebut; kesempatan-kesempatan apa yang diperoleh pembelajar dari tempat tersebut; apakah dia dapat menggunakan laboratorium bahasa, atau sarana lain yang dibutuhkan dalam pengajaran bahasa. Pembelajar juga dapat menanyakan tentang apa yang ditawarkan oleh kursus (sarana, guru, metode). Seandainya pembelajar sudah mendapat informasi yang diperlukan, ia dapat membandingkan apakah harapan-harapannya sesuai dengan apa yang ditawarkan oleh kursus dan apakah dia mendapat kesempatan seperti yang diharapkannya. Berdasarkan kenyataan itu pembelajar dapat memutuskan baik tidaknya suatu tempat kursus. 


\section{Apa yang Diinginkan Pembelajar Bahasa Asing}

Tujuan orang mempelajari bahasa asing bermacam-macam. Ada yang ingin belajar ke luar negeri, ada pula yang bertujuan supaya dapat membaca literatur dalam bahasa asing. Menurut Raasch (1986: 21) tujuan belajar bahasa asing ialah supaya dapat berhubungan dengan orang lain kemudian meningkat supaya dapat berkomunikasi. Apabila sudah dapat berkomunikasi diharapkan dapat saling memahami dan akhirnya saling pengertian. Belajar bahasa asing tidak sekedar dapat berbahasa, melainkan juga mengerti cara hidup dan kebiasaan orang yang bahasanya kita pelajari, di samping kita perlu mengenal lingkungan dan masalahnya. Setelah pembelajar mengetahui tujuan dan keinginannya dalam belajar bahasa asing, ada hal lain yang harus diperhatikan, yaitu linguistic performance dan lingusitic competence. Menurut Nuryanto (1993), untuk dapat berkomunikasi dalam suatu bahasa, pembelajar tidak cukup hanya memiliki linguistic competence dan linguistic performance, yakni kemampuan dan keterampilan untuk menggunakan kalimat-kalimat yang gramatikal, melainkan perlu pula mmemiliki communicative competence dan communicative performance, yakni kemampuan dan keterampilan untuk menggunakan kalimat-kalimat yang sesuai dengan konteks penggunaannya. Dengan demikian, pembelajar tidak cukup hanya mengetahui kaidah-kaidah kebahasaan dari bahasa yang digunakan, melainkan perlu pula mengetahui kaidah-kaidah fungsional unsurunsur bahasa yang bersangkutan.

\section{Cara Belajar Bahasa Asing}

Tujuan metode ialah mengantar pembelajar dari persepsi ke penyesuaian pengetahuan dan lebih jauh mengubah pengetahuan menjadi kemampuan. Dala m pengajaran bahasa asing, khususnya bahasa Jerman dikenal beberapa metode pengajaran bahasa, di antaranya sebagai berikut.

(1)Metode gramatik

Tujuan pengajaran bahasa Jerman pada saat metode ini dipergunakan adalah penguasaan tatabahasa dan kosa kata untuk keperluan pemahaman teks-teks bahasa Jerman. Metode ini, yang banyak dipakai pada tahun 60 -an hingga 70-an, menekankan pola keterampilan membuat kalimat yang benar secara gramatik, ia tidak memperhatikan keterampilan untuk menentukan pola-pola tatabahasa manakah, fungsi-fungsi ujaran bahasa manakah, ataupun kegiatan in teraksi sosial bagaimanakah yang tepat digunakan pada situasi tertentu.

(2)Metode audio-lingual

Titik berat pengajaran bahasa Jerman pada awal pertengahan 70-an hingga pertengahan 80-an adalah penguasaan bahasa lisan, sehingga metode pengajarannya pun beralih dari metode gramatik ke metode audio-lingual. 
(3) Metode langsung

Pada pertengahan tahun 80-an metode pengajaran yang banyak dipakai adalah metode langsung. Tujuan pengajaran masih tetap pada penguasaan bahasa lisan tanpa meninggalkan penguasaan bahasa tulis. Dengan metode ini pembelajar dilatih untuk menggunakan bahasa secara langsung.

(4) Pendekatan komunikatif

Mengenai pengajaran bahasa yang menggunakan pendekatan komunikatif ini, banyak ahli yang mengemukakan pendapatnya, antara lain Ute Gosewita (dalam Bauer 1984, lewat Subur tahun:1992: 6) sebagai berikut:

"dap durch die Wiederentdeckung und Neuformulierung des lehrziels 'Kommunikaionsfahigkeit' das Fremdsprachenlehren undlernen in wesentlichen verandert worden ist. Zudiesen Veranderungen zahlen beispielsweise".

(1) Sprachliche Auperungen werden in ihren kommunikativen Funktion dargestillt.

(2) Sprachliche Auperungen werden in ilhern Beziehungen betrachtet, in denen sie zu Sprechsituation, Sprechabsichten und Kommunikationspartnern stehen.

(3) Grammatische Korrekheit verliert als Bewertungskrite rium an Bedeutung, demgegenuber werden Kriterien wie "kommunikativ angemesser" oder "Kommunikation nicht gestort" wichtig.

(4) Die Progression wird nicht an der Grammatik, sondern an moglichen Kommunikationsfunktion ausgerichtet.

(5) Das verwendete Sprachmaterial wird stark am tatsach lichen Sprachgebrauch orientiert.

(6) Die Muttersprache wird als Erklar - und Beschreibungs sprache zugelassen, das Prinzip der absoluten Einsprachigkeit aufgehoben.

(7) Kognitives Lernen und Wissen uber Sprache als Mittel der Verstandigung erhalten eineri hohen Stellenwert.

Secara garis besar pendapat tersebut di atas dapat diringkas sebagai berikut: dengan adanya rumusan baru pengajaran bahasa, yaitu keterampilan komunikasi, pengajaran dan pembelajaran berubah. Perubahan-perubahan tersebut termasuk hal-hal berikut:

(1) Ujaran-ujaran bahasa dilakukan dalam fungsi-fungsi komunikatif.

(2) Ujaran-ujaran bahasa harus memperhatikan situasi pembicaraan, tujuan, dan lawan bicara.

(3) Kriteria penilaian yang lebih penting adalah ketepatan komunikasi.

(4) Kemajuan (hasil belajar) ditekankan pada fungsi komunikatif, bukan gramatik.

(5) Orientasi materi bahasa yang dipakai adalah pemakaian bahasa yang sebenamya dipakai dalam kenyataan (sehari- hari). 
(6) Bahasa ibu dipakai hanya untuk menerangkan atau menguraikan sesuatu. Pemakaian satu bahasa, dalam hal ini bahasa yang diajarkan lebih diutamakan.

(7) Belajar kognitif dan pengetahuan bahasa sebagai alat mendapat posisi penting.

Menurut Closset (1965: 29) metode yang paling cocok untuk pengajaran bahasa adalah metode "Arbeits- und Anschauungsunterrichts, bei denen der einzelne Schuler soweit wie eben moblich aktiv mitwirkend in das Klassengeschehen einbezogen wird. Aber der auf diese Wise zu erarbeitende Sprachstoff mu unter grammatikalischen Gesichtspunkten Systematisch gegliedert werden".

Inti pendapat tersebut menyebutkan, bahwa metode pengajaran bahasa yang paling tepat adalah metode pelajaran dengan ekskursi dan metode yang membiarkan pembelajar bekerja mandiri.

\section{Metode bermain}

Selain cara-cara yang telah disebutkan di atas, masih ada cara lain yang cukup penting, yakni metode bermain. Metode ini dapat diterapkan baik dalam pengajaran struktur, pemahaman bacaan, maupun percakapan.

Apabila guru akan mengadakan permainan hal-hal yang perlu diperhatikan adalah sebagai berikut:

(1) Permainan tidak boleh terlalu sulit ataupun terlalu mudah, melainkan sesuai dengan kemampuan pembelajar.

(2) Kata-kata penting, ungkapan dan kalimat yang dipakai dalam permainan ditulis di papan tulis dan dilatihkan sebelum permainan.

(3) Petunjuk permainan dan jalannya permainan dijelaskan lebih dahulu.

(4) Selama permainan sedapat mungkin guru tidak terlalu banyak mencampuri, hanya memperhatikan dengan cermat dan bertindak sebagai fasilitas.

(5) Jangan mengoreksi setiap kesalahan, supaya permainan tidak terhenti, di samping tidak mematikan keberanian anak.

(6) Mencatat kesalahan-kesalahan dan membahasnya setelah permainan selesai. Pada dasamya permainan ini dapat dilaksanakan sebagai berikut.

(1) Awal pelajaran, untuk membangkitkan dan memotivasi pembelajar.

(2) Akhir pelajaran yang menggembirakan, kalau masih ada sisa waktu lima menit.

(3) Kalau guru akan melatihkan atau mengulang sesuatu, misalkan bilangan, pola kalimat tanya, bentuk perfekt, dan sebagainya.

Waktu yang dipakai dalam permainan tergantung dari jenis permainannya, paling lama 30 menit. Banyak permainan yang cocok untuk pembelajar 
bahasa asing pemula. Manfaat permainan ini adalah untuk menghilangkan rasa takut pembelajar apabila akan berbicara.

Sebagai contoh di sini disajikan dua contoh permainan, masing-masing untuk pembelajar pemula dan lanjutan.

(1) Merkspiel (untuk pemula) (Schmidt, 1981)

Petunjuk bermain:

a. Guru menyiapkan kurang lebih sepuluh benda, yang diletakkan di atas meja sedemikian sehingga semua siswa dapat melihatnya.

b. Bila tidak dapat membawa bendanya dapat juga berupa gambar-gambar.

c. Berilah waktu satu menit kepada siswa untuk mengamati semua benda/gambar yang ada di meja.

d. Kemudian semua benda/gambar yang ada ditutupi.

e. Sekarang masing-masing siswa/kelompok siswa mencatat semua benda/gambar yang mereka lihat tadi.

Siapa yang paling banyak dapat mengidentifikasi dan menyebutkan bendabenda tersebut,adalah pemenangnya.

Tujuan belajar di sini ialah pemantapan kosakata

(2) Das Roboterspiel (untuk tingkat lanjutan) (Siregar, 1987) petunjuk bermain:

a. Bentuklah terlebih dahulu dua kelompok siswa misal Kelompok A dan B. Masing-masing kelompok menunjuk seorang wakil.

b. Wakil dari kelompok A akan memberikan perintah- perintah, yang harus dilaksanakan oleh robot, yaitu wakil dari kelompok B.

c. Sang robot hanya melaksanakan perintah, misalkan:

Siti soll fiir Anto ein Buch vom Tisch holen. Anto ist der Instruktur des Roboters. Er sagt: ... Steh auf! Dreh dich nach rechts - Geh einen Schritt vor - Streck den rechten Arm aus! Ninim das Buch vom Tisch. (Siti diminta mengambilkan Anto buku, sebagai instruktur Anto berkata: berdiri, berputar ke kanan, maju selangkah, ulurkan tangan kanan, ambil buku dari meja)

d. Kemungkinan-kemungkinan yang lain yaitu: das fenster aufmachen (buka jendela), die tafel abwischen (hapus papan tulis), Jemandem ein heft bringen (membawakan seseorang buku tulis). Latihan ini diulang $3 \mathrm{X}$

e. Kosa kata yang dapat diapaki antara lain membuka (aufmachen), menutup (zumachen), der schritt (langkah), nach rechts (ke kanan), nach links (ke kiri), nach unten (ke bawah), geradeaus (lurus) dan masih banyak kosa kata lainnya sesuai dengan keperluannya.

\section{Kesimpulan}

Dari beberapa metode yang diuraikan di atas, akhirnya guru juga yang menentukan metode mana yang paling tepat dipakai, karena gurulah yang 
paling mengetahui situasi dan keadaan kelas dan pembelajar. Jika dimungkinkan, guru menggabungkan beberapa metode (multimetode). Yang perlu diperhatikan ialah bahwa pengajaran bahasa asing bertujuan untuk memahami aturan-aturan pembentukan dan dapai menggunakannya.

\section{Daftar Pustaka}

Closset, Fr. 1965. Didaktik des neusprachlichen Unterrichts. Munchen: Max Hueber Verlag.

Nuryanto, F. 1993. Kemampuan Menggunakan Ragam Bahasa Indonesia Ilmiah di Kalangan Dosen IKIP Yogyakarta dan Kaitannya dengan Faktor-Faktor Pribadi. Yogyakarta: Laporan Penelitian.

Raasch, A. 1986. Fremdsprachen Lernen, aber wie? Munchen: Max Hueber Verlag.

Siregar-Fischer, Maria. 1987. Spiele fiir den Unterricht Deutsch als Fremdsprache. Jakarta: Arbeitspapier fiir den Grundkurs am Goethe-Institut Jakarta.

Sihombing, M. 1986. "Mahir berbahasa Jerman: Suatu Tantangan bagi Guru-guru Bahasa Jerman ", Lernen und Lehren: Jakarta, Th. 1986, No.1, h.: 11

Subur, dkk. 1992. Usaha-usaha untuk Menggalakkan Kegiatan Belajar Mengajar Bahasa Jerman di Kodya Yogyakarta dan sekitarnya. Yogyakarta: Laporan Pengabdian Pada Masyarakat. 